\title{
Incidence of Some Intestinal Parasites among Diabetic Patients Suffering from Gastroenteritis
}

\author{
Ola Salih $\mathrm{Ali}^{2}$, Shihab Ahmad Mohammad ${ }^{1}$ and Yahya Jirjees Salman ${ }^{3} *$ \\ ${ }^{1}$ Parasitology, ${ }^{2}$ College of Education for Pure Science-Tikrit University, Iraq \\ ${ }^{3}$ Medical Microbiology Faculty of Medicine-Kirkuk University, Iraq \\ *Corresponding author
}

\section{Keywords}

Gastroenteritis, diarrhea, IBS, IBD, Diabetic, Patient ages and gender

\section{Article Info}

Accepted:

20 July 2018

Available Online:

10 August 2018

\section{A B S T R A C T}

Intestinal parasites in association with gastroenteritis in Kirkuk city was recently reported among diabetic patients. To measure the incidence of parasitic infections depending on positive and negative rates in addition to stool components and types of gastroenteritis as irritable bowel syndrome (IBS) and inflammatory bowel disease (IBD) were investigated. A total of 419 patients were selected the gastroenteritis clinics in two Hospitals Kirkuk center. Their complaints were gastrointestinal disorders (GITDs), such as diarrhea, vomiting, nausea, diarrhea altered by constipation. The collected stool samples were examined for parasitological tests. Direct double wet preparations were performed for each stool sample then confirmed by flotation technique. In addition to modified Ziehl-Neelsen that applied for fecal smears for demonstrating the oocysts of Cryptosporiduim parvum. From the overall positive rate $82.81 \%$ for intestinal parasitic infections, only 62 patients with the rate14.79 \% were diabetic patients positive for the following parasites: Blastocystis hominis $35.48 \%$, Giardia lamblia $25.80 \%$, Entamoeba histolytica $17.74 \%$, Cryptosporidium parvum 12.90 and 6.45\%helminthic infections which involve Hymenolpis nana and Strongyloides stercoralis. According to the type of the gastroenteritis; female stool samples exert high rates of cryptosporidiosis, giardiasis high rates during IBS, while the high rate of helminthic infections was recorded in males, $\mathrm{P}<0.05$. Relationships between parasites incidences in regard of types of gastroenteritis, diarrhea existence, patients gender, ages, patient occupations, stool color, consistency, stool $\mathrm{pH}$ ranges and stool samples odor were significant, $\mathrm{P}<0.05$. The picture of gastroenteritis among diabetic patients accompanied with hypertension was serious especially in patients with IBS and the rate of intestinal infections was high $24.19 \%, \mathrm{p}<0.05$ Incidence of intestinal parasites among diabetes mellitus patients was high particularly among elderly patients. The picture of parasitic infections was serious particularly with invasive parasites and during hypertension.

\section{Introduction}

Intestinal parasitic infections was still a critical problem in developing countries particularly in Iraq in three last decades where continuous wars upon it disrupted the infrastructure of Iraq, that lead to poor sanitary conditions and lack of information resulted in 
the contamination of food and water with a consequent continuance of parasite cycles (Ali et al., 2018). Even in the some countries where education excel and adequate sanitation conditions, some of these parasites had an important role in causing diseases in specific groups such as immune-compromised individuals (Fantry, 2002), organ diseases such as diabetes (Nazligul et al., 2001), among renal failure patients (Gil et al., 2013).

It has been estimated that from about 340 parasitic infections, with varying mortality and morbidity among more than three billion people worldwide. They have an impact on an estimated 3.5 billion persons and cause clinical manifestation in approximately 450 million. The dominance of two main types of intestinal parasites is protozoa and helminthes and protozoa (WHO, 2014).

Diabetes mellitus (DM) is a group of metabolic communicable diseases in which a person blood glucose is high, either because cells do not respond to the insulin that is produced or because the body does not produce enough insulin or. (David et al., 2011) The persistence of this high blood sugar can exert the classical symptoms of polyuria, polydipsia, and polyphagia. Diabetes is one of the most frequent metabolic diseases and is widely distributed in various populations particularly among obese and food consumer rich by carbohydrate. Its frequency appears to be increasing rapidly in the recent decade (Belmokhtar et al., 2011).

The cause of diabetes can be triggered by certain infections, with some evidence pointing at Coxsackie B4 virus or depends on the type of diabetes as type-1-DM is partly inherited (Riserus et al., 2009). It has been found that type $1 \mathrm{DM}$ seems to require an environmental trigger, in addition to some genetic element in individuals susceptible to some of these triggers has been traced to particular human leukocyte antigen genotypes. However, even in those who have inherited the susceptibility. Moreover, type-2 DM is due primarily to genetics and lifestyle factors (Wild, 2004).

Intestinal parasites in the recent days take attention as important opportunistic pathogens responsible for clinically important infections in gastroenteritis patients in Kirkuk city-Iraq (Salman, 2015a; Hammood et al., 2016). Furthermore, the impact of the intestinal parasites was correlated by the estimation of fecal calprotectin among gastroenteritis patients by (Salman et al., 2017).

According to our information; studies regarding the intestinal parasites in relation to diabetes in Iraq are absent particularly among gastroenteritis patients in Kirkuk Province. So this study was planned to assess the existence of some intestinal parasites patients among gastroenteritis patients whom they have abnormal insulin metabolism (Diabetes).

\section{Materials and Methods}

\section{Study approval}

The study was approved by the Kirkuk Research and Publication Committee of Kirkuk Health Directorate (document number639 in March 2017), and by the respective Hospital Authorities at the two study hospitals. For all young patients, informed consent from the guardian on behalf of all the young patients enrolled in the study was taken. As well as done for elderly patients.

\section{Study design and patient selection}

From the 15th of March 2017 till the 1st February of 2018 a cross-sectional study was carried on; fecal samples were collected from 419 patients attending into Gastroenterology 
and Endoscopy Unit in Azadi teaching Hospital, Kirkuk General Hospital, Private clinics and Ibn-Nafees private medical laboratory in Kirkuk city. Patient selection was done under the supervision of the gastroenterologist. Patients enrolled in the study were 216 males and 203 females their ages were ranged from 1 year to over than 60 years. According to the physical examination; the following patients were enrolled in the study: 33 as IBS and 29 as IBD from a total of 176 IBS versus to171 IBD positive for intestinal parasites.

\section{Stool collection and examinations}

After a completion of all information on a special questionnaire for each patients, stool specimens were collected in a dry clean plastic container, leak- proof supported with fitted tight lid containing a small spoon labeled with an identification number. Stool samples were examined in the Department of Medical Microbiology, Faculty of Medicine, Kirkuk University and Ibn-Nafees Private Medical Laboratory.

Laboratory investigations: Macroscopic examination: This involved stool odor, color, consistency, and presence of blood or mucus. Microscopic examination involves the direct examination of double wet preparations of $0.90 \%$ of normal saline and $1 \%$ of Lugols Iodine-stain, these procedures were done according to (Salman, 2015 a).

Each specimen was confirmed for intestinal parasites by using concentration technique (Formal-ether) according to (Cheesbrough, 2009) and (WHO, 2003). Additionally, fecal smears where demonstrated for the oocysts of Cryptosporidium parvum after staining by hot modified Ziehl-Neelsen technique, this method was done according to Salman et al., (2015b).

\section{Statistical analysis}

All personal data in questionnaire form for each patient and extracted data from laboratory procedures were arranged in formal tables and tested statistically using some statistical equations to obtain the differences among all study parameters according to $\mathrm{P}$ value below 0.05 .

\section{Results and Discussion}

All rate of intestinal parasitic infection was $81.81 \%$ which include $14.7 \%$ patients whom they have DM. The negative rate in the current study was $17.79 \%, \mathrm{P}<0.05$; (Table 1 ).

Table 2 is showing the common intestinal parasites recorded in the currents study, via which intestinal protozoan parasites rate was $93.55 \%$ versus to $6.45 \%$ for helminthic infections, $\mathrm{p}<0.05$. The high rate of protozoan infection was $35.48 \%$ for Blastocystis hominis, followed by $25.80 \%$ for Giardia lamblia, $17.74 \%, 12.90 \%$ and $1.65 \%$ for Entamoeba histolytica, Cryptosporidium parvum and Iodomoeba butschlii $1.61 \%$, $\mathrm{p}<0.05$.whereas Hymenolips nana and Strongyloides stercoralis were recorded as $4.84 \%$ and $1.61 \%$ respectively. According to patient complain, diarrhea was recorded in 43 patients the rate was $69.35 \%$ in contrast to $30.65 \%$ for patients with constipation, $\mathrm{P}<0.05$.High rate of diarrhea was recorded with, Entamoeba histolytica and Blastocystis hominis, while Giardia lamblia was recorded equally as the patients have diarrheic and formed stool samples. Moreover Hymenolepis nana reveals a high rate of diarrhea $3.22 \% \%$ compares to Strongyloided stercoralis.

Gastroenteritis types were classified as IBD and IBS in diabetic patients, via which IBD was recorded in 29 patients compared to 33 patients with IBS, P>0.05. Statistically, the differences between intestinal parasites 
distribution and patient gender were significant, $\mathrm{P}<0.05$. Meanwhile, the variances were obvious in regard of Cryptosporidium infection, through which a high rate of IBS $23.52 \%$ was recorded in females with no record in males, $\mathrm{P}<0.05$. The same finding in regard of giardiasis $29.4 \%$ in females with IBS, contrary to this finding Entamoeba histolytica was recorded in males with IBS $37.5 \%$ compared to $14.28 \%$ with IBD patients. Helminthic infection was high among IBD patients $10.34 \%$ compared to $3.03 \%$ in patients with IBS, $\mathrm{P}<0.05$ (Table 3 ).

Considering the frequency of parasitic infections according to diabetic patients gender, female contribute $20.11 \%$ compared to $15.47 \%$ for males, $\mathrm{P}<0.05$. In females high rate of $8.42 \%$ of giardiasis was reported followed by $7.26 \%$ for Blastocystis hominis infections. While in male high rates $5.35 \%$ and $4.76 \%$ were recorded with and Blastocystis hominis and Entamoeba histolytica respectively. On the other hand, helminthic infection was highly frequent in female $2.23 \%$ compared to $0.59 \%$ in males, $\mathrm{P}<0.05$ (Table 4).

Regarding diabetic patient age; The following high rates of intestinal parasitic infections $51.62 \%$ and $32.52 \%$ were recorded among patient aging from 41 to 60 years and patients 61 and over respectively compare to other age groups, the relationship was significant, $\mathrm{P}<0.05$ (Table 5).

From A total of 62 diabetic patients with gastroenteritis, 15 of them have hypertension and the rate of parasitic infection was $24.19 \%$ compared to $47(75.81 \%)$ of diabetic patients non-hypertensive, $\mathrm{P}<0.05$. and according to types of gastroenteritis, they were classified into 37 IBS and 25 IBD with the following rates 59.68 and $40.32 \%$ for both respectively, $\mathrm{p}<0.05$. The relationship between hypertension and intestinal parasites frequency was significant, $\mathrm{P}<0.05$ via which; high rate $12.90 \%$ of positivity was recorded with Blastocytis hominis parasite with dominancy among IBS patients followed by 6. $45 \%$ for Giardia lamblia highly among IBD patients, the rate was $16.13 \%, \mathrm{P}<0.05$. Whereas, low rate $1.61 \%$ was recorded among patients infected with Cryptosporidium parvum which was seen in high rate $9.68 \%$ among IBS patients compared to $3.22 \%$ among IBD patients, $\mathrm{p}<0.05$ (Table 6).

Frequencies of intestinal parasites in diabetes patients according to occupation was shown in table 7 which was significant, through which high rate $48.38 \%$ of parasitic infection was recorded among females as house makers followed by 27.41 and $17.74 \%$ among workers and officers respectively

While a low rate $6.45 \%$ was recorded among students $; \mathrm{P}<0.05$. According to parasite species, Blastocystis hominis was highly frequent $52.94 \%$ among workers, while Cryptosporidium parvum was recorded in high $20 \%$ and $11.76 \%$ among House makers and workers with no recorded in officers and students. Moreover, Entamoeba histolytica, Giardia lamblia, and helminthic infections were highly recorded among officers than in other types of patient occupations, the rates were $27.28 \% \quad 36.36 \%$ and $18.18 \%$ respectively, $\mathrm{p}<0.05$.

Regarding stool color and consistency and intestinal parasites distribution, high rate of the positive parasite cases was found in brown stool $43.55 \%$ followed by $35.49 \%$ in a yellowish stool. While greenish and brown mucoid stool samples reveal the following low rates: $11.29 \%$ and $9.67 \%$ respectively, $\mathrm{P}<0.05$. According to parasite species, the following highest rates $36.36 \%, 62.5 \%$, and $40 \%$ were recorded with in yellowish liquid stool for Blastocystis hominis 
Cryptosporidium parvum infections respectively. Whereas $63.63 \%, 62.5 \%$ and 60 were found in brown liquid for Entamoeba histolytica, Giardia lamblia and for helminthic infections respectively, $\mathrm{P}<0.05$ (Table 8).

According to stool samples $\mathrm{pH}$, intestinal parasites were found in high rate in stool samples with $\mathrm{pH}$ ranged from 6.1 to 7 ; the rate was $46.74 \%$ compared to lower rate 12.90 in $\mathrm{pH}$ from 5 to $6, \mathrm{p}<0.05$. This high rate involves the following high rates: $62.5 \%$ $54.54 \%, 50 \%$ positive for Cryptosporidium parvum, Blastocystis hominis and Giardia lamblia respectively. Whereas $72.72 \%$ and $60 \%$ of positive cases were recorded in alkaline $\mathrm{pH}(7.1$ to 8$)$ for Entamoeba histolytica and helminths. Statistically, the relationship between fecal sample $\mathrm{pH}$ and intestinal parasites occurrence in diabetic patients was significant, $\mathrm{P}<0.05$ (Table 9).

Bad odor of stool samples most often with the intestinal parasite distribution, the rate was $51.09 \%$ followed by $37.09 \%$ was with mild odor compare to the low rate $11.30 \%$ of odorless stool samples positive for intestinal parasites, $\mathrm{P}<0.05$. High rates of bad stool odors $75 \%$ and $63.5 \%$ were recorded with Cryptosporidium parvum and Giardia lamblia parasites respectively.

Additionally, mild bad stool odor were smelled highly in samples positive for Entamoeba histolytica $63.64 \%$ followed by $40.90 \%$ for Blastocystis hominis compare to odorless high rate $20 \%$ for helminthic infections (Table 10).

Impacts of intestinal parasites upon the host depend on different factors such as parasite size, habitat, invasive or not, nutritional status, patients' immune system condition and other external factors. These impacts become more severe when it was accompanied by chronic diseases such as diabetes mellitus and hypertension. Consequently the rate of intestinal parasites among DM patients with gastroenteritis in current study $14.79 \%$ was high from the overall rate of parasitic infection $82.81 \%$.this rate was higher than that recorded in Cameroon by (Tangi et al., 2016) whom they recorded $10 \%$. The difference might be attributed to the size of samples examined in current study 419 compare to 235 samples examined in Cameroon. Whereas it was lower than that $18.7 \%$ in Nigeria recorded by (Akinbo et al., 20163)) and $47 \%$ in south-east Turkey by (Nazligul et al., 2001). Geographical location may account for this difference as the Olusegun et al (cited in Tangi et al., 2016) study was proceeded in Nigeria and the (Nazligul et al., 2001) study was done in Sanliurfa province which was an endemic zone for intestinal parasites.

Seven different intestinal parasites were identified, with five protozoa (Blastocystis hominis, Giardia lamblia E. histolytica, Cryptosporidium parvum and Idomoeba butshlii) and two helminths: Hymenolepis nana and Strongyloides stercoralis were identified. This differs from the study carried out in the same province Kirkuk-Iraq (Salman et al., 2017), whom they recorded only five species of protozoan parasites among gastroenteritis patients. The records of helminthes as Strongyloides stercoralis is very vital because this parasite when entering the body as larvae will migrate to lung for development and maturation they cause damages to the tissue and in the intestine they cause diarrhea and participate in gastroenteritis. Moreover it was lower than that recorded in Nigeria by (AKinbo et al., 2013); via which hookworm being the most frequent than three different intestinal parasites; while E. histolytica is the least prevalent. It also differs from the study carried out in South-east Anatolia (Nazligul 
et al., 2001) or Turkey where two different parasites where identified but the only protozoa were E. histolytica, G. lamblia and four helminths Ascaris, Trichuris trichuria and Taenias. Ascaris lumbricoides was the most prevalent intestinal parasite (WHO, 2004). In spite of the high rate of soil contamination in Iraq particularly in Kirkuk due different continuous war, economic sanction upon Iraq and lack of anti-helminths in addition to most of the anti-helminthic drugs are expensive. But helminthes were the least prevalent intestinal parasites in this study the rate was $6.54 \%$. The explanation to that might be due that the current study was cross-sectional not comprehensive to involve more peoples in Kirkuk Province. The record of high rate of Hymenolips nana reflect high rate of contamination and the people in Kirkuk Province live under poor hygienic condition and low level of sanitation (Salman et al., 2013).

Intestinal parasite interactions in the motility of the intestine depends on different factors such as the amount of parasite inoculum, parasite nature as invasive or not, parasite appendices such as cilia, flagella or pseudopodia and to teeth or cutting plates in Nematoda worm or to hooks in Cestoda worm and oral, ventral suckers in intestinal Trematoda worm (Paniker,2013). In current study diarrhea dominance with Blastocystis hominia and Giardia lamblia cases with high occurrence among Irritable bowel syndrome (IBS) can be explained by the fact to Blastocystis impact on the brush border of the intestine as well as that diarrhea is highly induced during IBS mostly related to environmental factors that eventually disturb patient health as anxiety, high rate of instability and aware (Hammood et al., 2016). Considering types of the diarrhea are important in the treatment of parasitic infection and to reduce the adverse effects of parasitic infections; such as liquid diarrhea without treatment during giardiasis most often give rise to malabsorption that subsequent to macrocytic hypochromic anemia (Ridley, 2012).

Diarrhea associated to Cryptosporidium parasite mostly water, explosive and sever particularly among young aged DM patients, this type of parasitic infection require medical interference and patient admission to Hospital to stop diarrhea, to compensate the fluid lost and to maintain hypovolemia (Salman et al., 2015b). Regarding diarrhea belongs to invasive Entamoeba histolytica $13.9 \%$ among IBD patients might be explained by the scientific fact that, Entamoeba extension in sub mucosa of the intestine give rise to flask shape ulcer, which considers as part of gastroenteritis due to large intestine ulceration (Sabah and Temsah, 2015). Relationship of intestinal amoebiasis is critical for DM patients, particularly when the case is extra-intestinal amoebiasis, during it more organs may involve and it was predicted that pancreas may involve especially among the immune-compromised patients (Panikers, 2013). Also helminthic infection rate $10.34 \%$ among IBD was high compared to $6.26 \%$ among IBS DM patients. This elevated rate might be attributed to the high rate of dwarf tapeworm ( $\mathrm{H}$. nana) record and the parasite colonization on brush border mostly produces diarrhea among IBS patient compare to sever diarrhea among IBD due to parasite scolex attachment and changing the scolex on brush border that will definitively form ulceration (Schmidt and Robert, 2009). This investigation reveals that there are more female participants who were also more infected $(20.11 \%)$ with intestinal parasites than males $(15.47 \%)$. This can be explained by the fact that the tendency of female for getting diabetes mellitus is higher than in males, this finding was similar to the study in Nigeria (Moutschennd et al., 1992) Sanliurfa province (Nazligul et al., 2001) Also females are more engaged in farming and domestic work during which they questing intestinal 
parasites. High records of Blastosystis hominis in the female, Giardia lamblia may have relation with IBS condition. Whereas high rate of Entamoeba histolytica in the female may have impact on female public health, because in nature they were more concern and contact with vegetables during meal preparation and most of the parasites may acquit under nail of female(Salma et $a l ., 2001)$. This finding did not agree with that recorded in Egypt by (Al-Nadi et al., 2015). Also there were parasitic infections in the age groups 41-60 years (13.3\%) and 61-80 years (7.8\%). Parasitic infections were not seen in the other age groups. This could be due to the diminished immune system that comes with aging coupled with diabetes mellitus status. Results were resembled to that done in Nigeria (where high rate of parasitic infections were revealed in patients aging from 51-60 years followed by 41-50 years and 61-70 years). While it was not compatible with that recorded in Libya by ElSeretie et al., (2006).

Correlation between parasitic infections and hypertension among diabetes patients with gastroenteritis was significant and vital for a physician in guiding the DM patients to avoid heart diseases, as the rate of hypertension was high with Blastocystis hominis than with other parasitic infections. Eradication of these parasites from DM patients was important because this parasite itself mostly associated with IBS than IBD and in nature one causes of IBS is an external factor that enhances high blood pressure which most like are life threating (Hammood et al., 2016b). Distribution of intestinal parasites among house makers DM patients in high rate 48.48 reflect the high rate of contamination through women exposure due to working in the houses as they were more contact with vegetables contaminated by infectious agents including intestinal parasites. In contrast high rate $27.41 \%$ among workers might be attributed to their contact with water most like contain a high amount of waterborne parasite due to weak monitoring of water quality in this Province. Moreover, the rate $17.74 \%$ among officer may reflect their consumption of prepared food (outdoor feeding) theses finding was compatible with that recorded by (Salman et al., 2017) and (Al-Bayati, 2011). However high rate 36.36 $\%$ of giardiasis among officer than in other occupations is critical for the health of DM patients, because it has been found that in Iraq most of giardia cases reveal resistance against anti-protozoan drugs (Salman and Mustafa, 2013). Therefore it may lead to malabsorption and that if left it will progress to macrocytic anemia associated with DM patients. The main causes for this elevated rate most like the return to that most government office do not have a special cafeteria for officer meals, so they depend on prepared food which may participate in this elevated giardia rate (Salman et al., 2016).

Correlation among stool color, consistency, odor and $\mathrm{pH}$ with a prevalence of intestinal parasite was not studied in detail in Iraq, except some studies which carried on Kirkuk province by Salman and Ali (2013), Salman (2015a) and Ali et al., (2018). Whom they found that during intestinal parasitic infection, stool samples converted in to liquid to semiliquid and during giardiasis, stool samples exert yellowish liquid to greasy appearance. And during Cryptosporidiosis the color was green. Also they found that most of the intestinal parasites were found in stool with $\mathrm{pH}$ ranges from 6.1 to 7 compared to acid and alkaline pH (Salman et al., 2015b). But in current study only Cryptosporidium parvum $62.5 \%$, Blastocystis homins $54.54 \%$ and Giardia lamblia $50 \%$ were found in a specimen with $\mathrm{pH} 6.1$ to 7 . This finding can be attributed to the habitat of these parasites in the upper part of the small intestine which has acidic to slightly $\mathrm{pH}$ (Hanivek et al., 2014). 
Table.2 Distribution of parasitic infections among diabetes patients in regard of diarrhea and constipation

\begin{tabular}{|c|c|c|c|c|c|c|}
\hline Diarrhea/ constipation & Diar & & Con & ation & Tot & \\
\hline Types of parasites & $*$ & & & & & \\
\hline Protozoa & No. & $\%$ & No. & $\%$ & No & $\%$ \\
\hline Blastocystis hominis & 15 & 24.19 & 7 & 11.29 & 22 & 35.48 \\
\hline Cryptosporidium parvum & 6 & 9.67 & 2 & 3.22 . & $\mathbf{8}$ & 12.90 \\
\hline Entamoeba histolytica & 11 & 17.74 & $\mathbf{0}$ & $\mathbf{0}$ & 11 & 17.74 \\
\hline Giardia lamblia & 8 & 12.90 & 8 & 12.90 & 16 & 25.80 \\
\hline Iodomoeba butschlii & $\mathbf{0}$ & $\mathbf{0}$ & 1 & 1.61 & 1 & 1.61 \\
\hline Total protozoan infections & 40 & 64.51 & 18 & 29.03 & $\begin{array}{l}\mathbf{5 8} \\
93.5\end{array}$ & \\
\hline Helminthes & No. & $\%$ & & & & \\
\hline Strongyloides stercoralis & 1 & 1.61 & $\mathbf{0}$ & $\mathbf{0}$ & 1 & 1.61 \\
\hline Hymenolips nana & 2 & 3.22 & 1 & 1.61 & 3 & 4.84 \\
\hline Total helminthic infections & 3 & 4.83 & 1 & 1.61 & 4 & 6.45 \\
\hline All total & 43 & 69.35 & 19 & 30.65 & 62 & 100 \\
\hline
\end{tabular}

$\mathrm{a}$ and $\mathrm{b} \quad \mathrm{P}<0.05 \quad$ Total diabetes patients positive for parasites $=62$.

Table.3 Relationship between parasite distribution among diabetes patients in regard of type of gastroenteritis and patient gender

\begin{tabular}{|c|c|c|c|c|c|c|c|c|c|c|c|c|}
\hline \multirow{3}{*}{\begin{tabular}{|l} 
Diseases \\
Gender \\
parasites \\
\end{tabular}} & \multicolumn{6}{|c|}{ Inflammatory bowel disease( IBD) } & \multicolumn{6}{|c|}{ Irritable bowel syndrome (IBS) } \\
\hline & \multicolumn{2}{|c|}{ Males } & \multicolumn{2}{|c|}{ Females } & \multicolumn{2}{|c|}{ Total } & \multicolumn{2}{|c|}{ Males } & \multicolumn{2}{|c|}{ Females } & \multicolumn{2}{|c|}{ Total } \\
\hline & No & $\%$ & No & $\%$ & No & $\%$ & No & $\%$ & No & $\%$ & No & $\%$ \\
\hline \begin{tabular}{|l|} 
Blastocystis \\
hominis
\end{tabular} & 7 & 50 & $\mathbf{3}$ & 20 & 10 & 34.48 & 6 & 37.5 & 6 & 35.29 & 12 & 36.36 \\
\hline $\begin{array}{l}\text { Cryptosporidium } \\
\text { parvum }\end{array}$ & 1 & 7.14 & 3 & 20 & 4 & 13.79 & o & 0 & 4 & 23.52 & 4 & 12.12 \\
\hline $\begin{array}{l}\text { Entamoeba } \\
\text { histolytics } \\
\end{array}$ & 2 & 14.28 & 2 & 13.33 & 4 & 13.79 & 6 & *37.5 & 1 & 5.89 & 7 & 21.21 \\
\hline Giardia lamblia & 4 & 28.56 & 4 & 26.66 & 8 & 27.58 & 3 & 18.75 & 5 & $* 29.41$ & 8 & 24.24 \\
\hline Iodomoeba butschili & o & $\mathbf{0}$ & o & 0 & 0 & $\mathbf{0}$ & o & 0 & 1 & $* 5.89$ & 1 & 3.03 \\
\hline Helminthes & D & $\mathbf{0}$ & 3 & 20 & 3 & 10.34 & 1 & 6.26 & 0 & $\mathbf{0}$ & 1 & $\mathbf{3 . 0 3}$ \\
\hline Total & 14 & 100 & 15 & 100 & 29 & 100 & 16 & 100 & 17 & 100 & 33 & 100 \\
\hline
\end{tabular}


Table.1 positive and negative rates for parasitic infection and the positive rate among diabetes patients

\begin{tabular}{|l|rl|}
\hline Types of infection and diseases & No & $\%$ \\
\hline Infected patients & 347 & 82.81 \\
\hline Non-infected & 72 & 17.19 \\
\hline Diabetes patients positive for parasites & 62 & $14.79 *$ \\
\hline Total number examined & 419 & 100 \\
\hline
\end{tabular}

$* \mathrm{P}<0.05$.

Table.4 Frequencies of parasitic infections according patients gender

\begin{tabular}{|c|c|c|c|c|c|c|c|c|c|c|}
\hline \multirow[t]{2}{*}{ Genders } & \multicolumn{4}{|c|}{ Males * } & \multicolumn{4}{|c|}{ Females } & \multicolumn{2}{|c|}{ - } \\
\hline & \multicolumn{2}{|c|}{$\begin{array}{l}\text { All positive } \\
\text { in the study }\end{array}$} & \multicolumn{2}{|c|}{$\begin{array}{c}\text { Positive } \\
\text { In diabetes } \\
\text { patients }\end{array}$} & \multicolumn{2}{|c|}{\begin{tabular}{|l} 
All \\
positive in \\
the study
\end{tabular}} & \multicolumn{2}{|c|}{\begin{tabular}{|c|} 
Positive \\
in diabetes \\
patients
\end{tabular}} & \multicolumn{2}{|c|}{\begin{tabular}{|c} 
All positive \\
in diabetes \\
patients
\end{tabular}} \\
\hline parasites & No & $\%$ & No & $\%$ & No & $\%$ & No & $\%$ & No & $\%$ \\
\hline Blastocystis hominis & 39 & 23.21 & 9 & 5.35 & 61 & 34.27 & 13 & $* 7.26$ & 22 & 6.34 \\
\hline Cryptosporidium parvum & 7 & 4.16 & $\mathbf{1}$ & 0.59 & 18 & 10.11 & 7 & $* 3.91$ & 8 & 2.30 \\
\hline Entamoeba histolytics & 57 & 33.92 & 8 & $* 4.76$ & 46 & 25.84 & 3 & 1.67 & 11 & 3.17 \\
\hline Giardia lamblia & 46 & 27.38 & 7 & 4.16 & 42 & 23.59 & 9 & $* 8.42$ & 16 & 4.61 \\
\hline Helminthes & 9 & 5.35 & $\mathbf{1}$ & 0.59 & 24 & 13.48 & 4 & * 2.23 & 5 & 1.44 \\
\hline Total & 168 & 8.41 & 26 & 15.47 & 179 & 51.59 & 36 & *20.11 & 62 & $\mathbf{1 7 . 8 6}$ \\
\hline
\end{tabular}

*All male positive for parasites $=168$ (10 positive samples were discarded $)$. Total No.exam=419

Table.5 Distribution of intestinal parasitic infections according to patients ages

\begin{tabular}{|c|c|c|c|c|c|c|c|c|c|c|c|c|}
\hline & \multicolumn{2}{|c|}{$\begin{array}{l}\text { Blastocystis } \\
\text { hominis }\end{array}$} & \multicolumn{2}{|c|}{$\begin{array}{l}\text { Cryptosporidium } \\
\text { parvum }\end{array}$} & \multicolumn{2}{|c|}{$\begin{array}{r}\text { Entamoeba } \\
\text { histolytica }\end{array}$} & \multicolumn{2}{|c|}{$\begin{array}{l}\text { Giardia } \\
\text { lamblia }\end{array}$} & \multicolumn{2}{|c|}{ Helminthes } & \multicolumn{2}{|c|}{$\begin{array}{c}\text { Total } \\
*\end{array}$} \\
\hline $\begin{array}{l}\text { Age } \\
\text { groups/Y }\end{array}$ & No & $\%$ & No & $\%$ & No & $\%$ & No & $\%$ & No & $\%$ & & $\%$ \\
\hline 1 to 20 & 2 & 3.22 & 0 & $\mathbf{0}$ & 1 & 1.61 & 1 & 1.61 & $\mathbf{0}$ & $\mathbf{0}$ & 4 & 6.45 \\
\hline 21 to 40 & 1 & 1.61 & 1 & 1.61 & 2 & 3.22 & 2 & 3.22 & (0 & $\mathbf{0}$ & 6 & 9.68 \\
\hline 41 to 60 & 14 & 22.58 & 6 & 9.67 & 5 & 8.06 & 6 & 9.68 & 1 & 1.61 & 32 & 51.62 \\
\hline 61 above & 5 & 8.06 & 1 & 1.61 & 3 & 4.83 & 7 & 11.29 & 4 & 6.45 & 20 & 32.25 \\
\hline Total & & 35.48 & $\begin{array}{l}8 \\
12.9\end{array}$ & & $\begin{array}{l}11 \\
17.7\end{array}$ & & 16 & 25.80 & 5 & 8.06 & 62 & 100 \\
\hline
\end{tabular}

\footnotetext{
*p $<0.05 \quad$ Total number examined $=62$
} 
Table.6 Correlation between parasitic infections and hypertension among diabetes patients with gastroenteritis

\begin{tabular}{|c|c|c|c|c|c|c|c|c|}
\hline Types of diseases & IBD & & IBS & & Hyper & ensive & Non & pertensive \\
\hline parasites & No & $\%$ & No & $\%$ & No & $\%$ & No & $\%$ \\
\hline $\begin{array}{l}\text { Blastocystis } \\
\text { hominis }\end{array}$ & 6 & 9.67 & 16 & 25.81 & $\begin{array}{l}8 \\
12.90 *\end{array}$ & & 14 & $22.58 *$ \\
\hline $\begin{array}{l}\text { Cryptosporidim } \\
\text { parvum }\end{array}$ & 2 & 3.22 & 6 & $9.68 *$ & 1 & 1.61 & 7 & 11.29 \\
\hline $\begin{array}{l}\text { Entamoeba } \\
\text { histolytics }\end{array}$ & 5 & 8.06 & 6 & 9.68 & $\begin{array}{l}2 \\
3.22\end{array}$ & & 9 & 14.51 \\
\hline Giardia lamblia & 10 & $16.13 *$ & 6 & 9.68 & 4 & 6.45 & 12 & 19.35 \\
\hline Helminthes & 2 & 3.22 & 3 & 4.83 & $\mathbf{0}$ & 0.0 & 5 & 8.06 \\
\hline Total & 25 & 40.32 & 37 & 59.68 & 15 & 24.19 & 47 & 75.81 \\
\hline
\end{tabular}

*p<0.05.

Table.7 Frequencies of intestinal parasites among diabetes patients according to occupation

\begin{tabular}{|c|c|c|c|c|c|c|c|c|c|c|c|c|}
\hline \multirow{3}{*}{$\frac{\text { parasites }}{\text { Occupations }}$} & \multirow{2}{*}{\multicolumn{2}{|c|}{$\begin{array}{l}\text { Blastocystis } \\
\text { hominis }\end{array}$}} & \multirow{2}{*}{\multicolumn{2}{|c|}{$\begin{array}{l}\text { Cryptosporidium } \\
\text { parvum }\end{array}$}} & \multirow{2}{*}{\multicolumn{2}{|c|}{$\begin{array}{l}\text { Entamoeba } \\
\text { histolytica }\end{array}$}} & \multirow{2}{*}{\multicolumn{2}{|c|}{$\begin{array}{l}\text { Giardia } \\
\text { lamblia }\end{array}$}} & \multirow{2}{*}{\multicolumn{2}{|c|}{ helminthes }} & \multirow{2}{*}{\multicolumn{2}{|c|}{ Total }} \\
\hline & & & & & & & & & & & & \\
\hline & No & $\%$ & No & $\%$ & No & $\%$ & No & $\%$ & No & $\%$ & No & $\%$ \\
\hline $\begin{array}{l}\text { House } \\
\text { makers }\end{array}$ & 9 & 30 & 6 & $20 *$ & & 16.66 & & 23.33 & & 10 & 30 & 48.38* \\
\hline Workers & 9 & $52.94 *$ & 2 & 11.76 & 2 & 11.76 & & 23.52 & $\mathbf{0}$ & 0.0 & 17 & 27.41 \\
\hline Officers & 2 & 18.18 & 0 & $\mathbf{0}$ & & $27.28 *$ & & 36.36* & 2 & 18.18* & 11 & 17.74 \\
\hline Students & 2 & 50 & 0 & $\mathbf{0}$ & 1 & 25 & 1 & 25 & $\mathbf{0}$ & $\overline{0}$ & 4 & 6.45 \\
\hline Total & 22 & 35.48 & 8 & 12.90 & 11 & 17.74 & 16 & 25.8 & 5 & 8.06 & 62 & 100 \\
\hline
\end{tabular}

$* \mathrm{P}<0.05$.

Table.8 Distribution of intestinal parasites according to stool color and consistencies

\begin{tabular}{|c|c|c|c|c|c|c|c|c|c|c|c|c|}
\hline \multirow{3}{*}{$\begin{array}{l}\text { Parasites؛ } \\
\text { Color }\end{array}$} & \multirow{2}{*}{\multicolumn{2}{|c|}{$\begin{array}{c}\text { Blastocystis } \\
\text { hominis }\end{array}$}} & \multirow{2}{*}{\multicolumn{2}{|c|}{$\begin{array}{l}\text { Cryptosporidium } \\
\text { parvum }\end{array}$}} & \multirow{2}{*}{\multicolumn{2}{|c|}{$\begin{array}{l}\text { Entamoeba } \\
\text { histolytica }\end{array}$}} & \multirow{2}{*}{\multicolumn{2}{|c|}{$\begin{array}{l}\text { Giardia } \\
\text { lamblia }\end{array}$}} & \multirow{2}{*}{\multicolumn{2}{|c|}{ Helminthes }} & \multirow{2}{*}{\multicolumn{2}{|c|}{ Total }} \\
\hline & & & & & & & & & & & & \\
\hline & No & $\%$ & No & $\%$ & No & $\%$ & No & $\%$ & No & $\%$ & No & $\%$ \\
\hline Brown & 6 & 27.27 & 1 & 12.5 & 7 & 63.63 & 10 & 62.5 & 3 & 60 & 27 & $43.55 *$ \\
\hline $\begin{array}{l}\text { Brown } \\
\text { Mucoid }\end{array}$ & 5 & 22.72 & $\mathbf{0}$ & 0.0 & 1 & 9.09 & 0 & 0.0 & 0 & $\mathbf{0}$ & 6 & 9.67 \\
\hline Green & 3 & 13.63 & 2 & 25 & 1 & 9.09 & 1 & 1.61 & 0 & 0 & 7 & 11.29 \\
\hline Yellow & 8 & 36.36 & 5 & 62.5 & 2 & 18.18 & 5 & 8.06 & 2 & 40 & 22 & 35.49 \\
\hline Total & 22 & 35.48 & 8 & 12.90 & 11 & 17.74 & 16 & 25.8 & 5 & 8.06 & 62 & 100 \\
\hline
\end{tabular}

Total number diabetes patient positive for parasites $=62$

$* \mathrm{p}<0.05$. 
Table.9 Distribution of intestinal parasites according to stool $\mathrm{pH}$

\begin{tabular}{|c|c|c|c|c|c|c|c|c|c|c|c|c|}
\hline \multirow{3}{*}{$\begin{array}{l}\text { Parasites } \\
\text { Stool pH } \\
\text { ranges }\end{array}$} & \multirow{2}{*}{\multicolumn{2}{|c|}{$\begin{array}{c}\text { Blastocystis } \\
\text { hominis }\end{array}$}} & \multirow{2}{*}{\multicolumn{2}{|c|}{$\begin{array}{l}\text { Cryptosporidium } \\
\text { parvum }\end{array}$}} & \multirow{2}{*}{\multicolumn{2}{|c|}{$\begin{array}{l}\text { Entamoeba } \\
\text { histolytica }\end{array}$}} & \multirow{2}{*}{\multicolumn{2}{|c|}{$\begin{array}{l}\text { Giardia } \\
\text { lamblia }\end{array}$}} & \multirow{2}{*}{\multicolumn{2}{|c|}{ Helminthes }} & \multirow{2}{*}{\multicolumn{2}{|c|}{ Total }} \\
\hline & & & & & & & & & & & & \\
\hline & No & $\%$ & No & $\%$ & No & $\%$ & No & $\%$ & No & $\%$ & No & $\%$ \\
\hline 5 to 6 & 5 & $22.28 *$ & 0 & $\mathbf{0}$ & 1 & 9.09 & 2 & 12.5 & 0 & $\mathbf{0}$ & 8 & 12.90 \\
\hline 6.1 to 7 & & 54.54 & 5 & $62.5 *$ & 2 & 18.8 & 8 & 50.0 & 2 & 40 & 29 & 46.74* \\
\hline 7.1 to 8 & 5 & 22.28 & 3 & 37.5 & 8 & 72.72* & 6 & 37.5 & 3 & 60 & 25 & 40.32 \\
\hline Total & 22 & 35.48 & 8 & 12.90 & 11 & 17.74 & 16 & 25.8 & 5 & 8.06 & 62 & 100 \\
\hline
\end{tabular}

Table.10 Distribution of intestinal parasites according to stool odor

\begin{tabular}{|c|c|c|c|c|c|c|c|c|c|c|c|c|}
\hline \multirow{3}{*}{$\frac{\text { Parasites؛ }}{\text { Stool odor }}$} & \multirow{2}{*}{\multicolumn{2}{|c|}{$\begin{array}{l}\text { Blastocystis } \\
\text { hominis }\end{array}$}} & \multirow{2}{*}{\multicolumn{2}{|c|}{$\begin{array}{l}\text { Cryptosporidium } \\
\text { parvum }\end{array}$}} & \multirow{2}{*}{\multicolumn{2}{|c|}{$\begin{array}{l}\text { Entamoeba } \\
\text { histolytica }\end{array}$}} & \multirow{2}{*}{\multicolumn{2}{|c|}{$\begin{array}{l}\text { Giardia } \\
\text { lamblia }\end{array}$}} & \multirow{2}{*}{\multicolumn{2}{|c|}{ Helminthes }} & \multirow{2}{*}{\multicolumn{2}{|c|}{ Total }} \\
\hline & & & & & & & & & & & & \\
\hline & No & $\%$ & No & $\%$ & No & $\%$ & No & $\%$ & No & $\%$ & No & $\%$ \\
\hline odorless & 4 & 18.18 & 1 & 12.5 & 0 & $\overline{\mathbf{0}}$ & 1 & 6.25 & 1 & 20 & 7 & 11.30 \\
\hline Mild odor & 9 & 40.90 & 1 & 12.5 & 7 & 63.64* & 5 & 31.25 & 3 & 60* & 23 & 37.09 \\
\hline Bad odor & 9 & 40.90 & 6 & $75.0 *$ & 4 & 36.36 & 10 & 63.5* & 1 & 20 & 32 & 51.61* \\
\hline Total & 22 & 35.48 & 8 & 12.90 & 11 & 17.74 & 16 & 25.8 & 5 & 8.06 & 62 & 100 \\
\hline
\end{tabular}

While high rate of Entamoeba histolytica $72.72 \%$, and helminths $60 \%$, the real cause to this finding might be due to that Entamoeba histolytica is invasive parasite that causes destruction of fine blood capillary during extension from brush border to mucosa and the blood may interfere the $\mathrm{pH}$ assessment or due to the $\mathrm{pH}$ of large intestine itself is slightly alkaline (Salman et al '2014). Regarding the high rate $43.55 \%$ of intestinal parasite frequency in brown color than other stool samples color, this finding might be related to nutrition and most of the patients were adult. While high rate $35.49 \%$ of yellow stool this might be related to the digestion of bilirubin and biliverdin digestions and also a proper number of the patients were below 12 years in which yellowish stool due to nutrition (Estridge and Reynolds, 2008).
Bad odor of stool samples in high rates with Giardiasis and Cryptosporidiosis might be due to parasite metabolism via which high amount of $\mathrm{H} 2 \mathrm{~S}$ gases produced or due to digestion action as normal intestinal flora digest mostly under an aerobic condition (fermentation) (Cotton et al., 2011).While mild stool odor during intestinal amoebiasis might be related to intestinal ulceration and to the secondary bacterial infection (Tanyuksil and Petri, 2003). In addition the odor might be related to gastroenteritis as IBS or IBD (Salman et al., 2015c).

In conclusion, the incidence of intestinal parasites among diabetes mellitus patients was high particularly among elderly patients. The following parameters, patient age, gender, occupation, stool color, consistency, 
and the odor are significant for gastroenteritis classification. The picture of parasitic infections was serous particularly with invasive parasites and during hypertension.

\section{Acknowledgement}

The authors would like to thank all gastroenteritis physicians particularly $\mathrm{dr}$. samar saad, Aswad Habeeb and Jasim Mohammad for patient selection. Thanks to all the diabetes patients attending the Kirkuk Regional Hospitals Diabetic unit and private clinics, who accepted to participate in this study. Author reserves special thanks to all laboratory technicians in Ibn-nafees private medical laboratory for their technical assistance and genuine criticism throughout this work.

\section{Conflicts of Interest}

The authors declare that they have no conflicts of interest.

\section{References}

Akinbo, F., Olujobi, O., Omoregie, Rand Egbe, C. Intestinal parasitic infections among diabetes mellitus patients. Biomarkers and Genomic Medicine. 2013; 5: 44-47. doi: 10.1016/j.gmbhs. 2013.05.003.

AL-Bayati, Sh. R. W. Epidemiological study on some intestinal pathogenic protozoa in Toze town-Tikrit-Iraq, with histological feature during giardiasis in Balb-C lab animal. M.Sc. thesis. Coll Educ. Tikrit Univ.2011.

Ali, O. S., Mohammad, SH. A. and Salman, Y. J. Relationship between Entamoeba histolytica and Fecal Calprotectin in Patients with Gastroenteritis in Kirkuk City-Iraq. Egyptian Journal of Medical Microbiology. 2018 April; 27(2): 4956.
Alsirieti, S.R.A., Elahwel, A.M, Elamari, A.A. Intestinal Protozoa in Libyan patients in Sirt. Jamahiriya Med J. 2006; 6: 59-61.

Belmokhtar, F., Belmokhtar, F., Dali-Sahi, D.Risk factors associated with type 2 diabetes mellitus in west region of Algeria, Maghnia. J Diabetes Metab, 2011: 148-150.

Cheesbrough, M. District laboratory practice in tropical countries. 2 nd ed updated. Cambridge University Press; 2009:183-191.

Cotton, J.A., Beatty, J.K and Buret, A.G. Host parasite interactions and pathophysiology in Giardia infections. Int. J. Parasitol. 2011, 41, 925-933.

David,G., Gardner, R. and Greenspan's, D. Basic and Clinical Endocrinology (9th ed.), McGraw-Hill Medical, New York 2011: 200-220.

El Nadi, N.A., Hassanien, H.A., Ahmad, A.M and AbdEllah, AK. Intestinal parasites in diabetic patients in Sohag University Hospitals, Egypt. J. Egypt Soc. Parasitol. 2015; 45, 2:443-9.

Estridge, B. H. and Reynolds, A. P. Basic clinical laboratory techniques (5th ed.). Clifton Exot. 2008 5:725-730.

Fantry L. Gastrointestinal infections in the immunocompromised host. Curr Open Gastroenterol. 2002; 18:34-39.

Gil, F.F., Barros, M.J., Macedo N.A. Prevalence of intestinal parasitism and associated symptomatology among hemodialysis patients. Rev. Inst. Med. Trop. Sao Paulo. 2013; 55(2): 69-74.

Hammood, A.M., Salman, Y.J. and Ahmed, B.A. Possible Association between Blastocystis hominis and Bowel Disorders among Iraqi Patients in Kirkuk Province. Int.J.Curr.Res.Aca. Rev. 2016 a; 4(7): 50-56.

Hammood, A.M., Ali, B.A. and Salman, Y. J. Blastocystis hominis detection among gastrointestinal disorders' patients in 
Kirkuk province using three different laboratory methods. Int.J.Curr. Microbiol.App.Sci 2016 b; 5(7): 883901.

Hanevik, K., Wensaas, K.A.,Rortveit, G., Eide, G.E., Morch, K. and Langeland, N. Irritable bowel syndrome and chronic fatigue 6 years after Giardia infection: A controlled prospective cohort study. Clin. Infect. Dis. 2014, 59, 1394- 1400.

Moutschen, M.P., Scheen, A.J and Lefebvre, P.J. Impaired immune responses in diabetes mellitus: analysis of the factors and mechanisms involved: relevance to the increased susceptibility of diabetic patients to specific infections. Diabete Metab. 1992; 18: 187-201.

Nazligul, Y., Sabuncu, T. and Ozbilge H. Is there a predisposition to intestinal parasitosis in diabetic patients? Diabetes Care. 2001; 24: 1503-1504. doi: 10.2337/diacare. 24.8.1503.

Ridley, J. W. Parasitology for clinical and laboratory professionals. Cengage Learning Customer \& Sales Support, USA. 2012:1-12.

Panikar, J.C.D. Panikars text book mfor medical parasitology. $7^{\text {th }}$.edit. Jaypee Brothers medical publisher. India, 2013: 9 to 29.

Schmidt, G.D. and Roberts, L.S. Foundation of parasitology. Eight edit. The McGraw-Hill Companies, Inc. USA. 2009:313-329.

Riserus, U, Willett W C and HU, F B. Dietary fats and prevention of type 2 diabetes Progin Lipid Res. 2009;8: 44-51.

Sabah,A.A and Temsah,A.G. Prevalence of some gastro-intestinal parasites in diabetic patients in Tanta city, Gharbia governorate, Egypt. J. Egypt. Soc. Parasitol. (JESP), 45(3), 2015: 681 684.

Salman, Y., Al-Alousi, T. and Hamad, S.
Prevalence of intestinal parasites among people in Kirkuk city. Almustansiriya J. Sci. 2001; 1: 12-20.

Salman, Y.J. and Ali, L.S. Detection of some microbial infection among children aging below 2 years in Kirkuk city. J Kirkuk Med Coll 2013 a; 1(1):53-60.

Salman,Y.J. and Mustafa, M.I. Evaluation of the employment of four laboratory diagnostic methods of detecting Gairdia lamblia among Children in Kirkuk city. J Kirkuk Med Coll 2013 b; 1(2): 52-60.

Salman, Y.J. Efficacy of some laboratory methods in detecting Giardia lamblia and Cryptosporidium parvum in stool samples. Kirkuk Univ. J. Sci. Stud 2014.; 9(1): 717.

Salman, Y.J. Detection of Blastocystis hominis among Peoples in Kirkuk Province Using ELISA and Direct Microscopy". Int. J. Curr. Microbiol. App. Sci.2015a; 4(10): 686-695.

Salman,Y. J., Sadek, W. S and Rasheed Z KH. Prevalence of Cryptosporidium parvum among Iraqi displaced people in Kirkuk city using direct microscopy, flotation technique and ELISA copro-antigen. Int.J.Curr. Microbiol. App. Sci, 2015b; 4(11): 559-572.

Salman, Y.J., Kadir, M.A and Abdul-Allah, T.J. Prevalence of Cyclospora cayetanensis and other intestinal parasites in soil samples collected from Kirkuk province. Int. J. Curr. Res. Aca. Rev 2015c, 3(10): 239250.

Salman,Y. J., AL-Taee, A. A and Abid, A. M. Prevalence of Giardia lamblia among Iraqi Displaced Peoples in Kirkuk Province. Int.J.Curr.Microbiol.App. Sci. 2016; 5(1): 753-760.

Salman, Y. J., Ali,CH. A and Abdulrazaq, A. A. Fecal calprotectin among patients infected with some protozoan infections. International Journal of 
Current Microbiology and Applied Sciences.2017;6(6):3258-3274.

Tangi, F. B., Fokam, E. B., LOngdoh, N. A. and Eteneneng, $\mathrm{E}$ J. Intestinal Parasites in Diabetes Mellitus Patients in the Limbe and Buea Municipalities, Cameroon. Diabetes Res Open J. 2016; 2(1): 1-7.

Tanyukse, Ml and Jr, W.B.P. Laboratory diagnosis of amebiasis. Clinical Microbiology Reviews2003,

Wild, S., Roglic,G. and Green, A. Global prevalence of diabetes: estimates for the year 2000 and projections for the year 2030 J Diabetes Care. 2004;27: 1047-1053.

World Health Organization. Manual to medical laboratory investigations. WHO Geneva, 2003.

World Health Organization. Integrated guide to sanitary parasitology. WHO Geneva.2004:2-4

World Health Organization. Infectious Diseases Home Page. Intestinal parasites, WHO Geneva, 2014.

\section{How to cite this article:}

Ola Salih Ali, Shihab Ahmad Mohammad and Yahya Jirjees Salman. 2018. Incidence of Some Intestinal Parasites among Diabetic Patients Suffering from Gastroenteritis. Int.J.Curr.Microbiol.App.Sci. 7(08): 3695-3708. doi: https://doi.org/10.20546/ijcmas.2018.708.375 